\title{
RANCANG BANGUN SISTEM INFUS CERDAS
}

\author{
Hamzah $^{\text {1) }}$,Ardi_Amir $^{2)}$,Yulius S Pirade ${ }^{3)}$,Maryantho Masarrang ${ }^{4)}$ \\ ${ }^{1)}$ Mahasiswa Teknik Elektro Universitas Tadulako \\ ${ }^{2,3,4)}$ Dosen Jurusan Teknik Elektro Universitas Tadulako \\ Program Studi S1 Teknik Elektro, Fakultas Teknik, Universitas Tadulako \\ e-mail : hamzahraginda@gmail.com
}

\begin{abstract}
The rapid development of the world of technology that covers almost all sides of life has encouraged innovation and human creation to make various tools with automatic work systems. Giving fluids using intravenous fluids is one way to enter fluids intravenously to meet the needs of fluids, electrolytes, drug administration, and feeding. The process of replacing intravenous fluids that has reached the minimum replacement limit must be carried out promptly and quickly, so that there will be no delay in changing intravenous fluids which will result in unstable pressure on the infusion set which will result in blood clots.

In its testing, this tool can display information on the total number of intravenous fluid drops, and the condition of the remaining infusion fluid level on the LCD, as well as an additional display of the number of intravenous fluid drops per minute on theapplications client $\mathrm{PC}$ and / or smartphone. Adjusting the position of the mini servo of the infusion tap, can be adjusted when the appliance is not or not connected to the client. The sensor optocoupler used can also detect every drop of intravenous fluid. The reading of the sensor optocoupler used can experience an error by a difference of $100 \%$ if the dripping of the intravenous fluid is too slow. This is caused by the drip that is read twice by the sensor because one drop of intravenous fluid is read again after more than 50 milli second.
\end{abstract}

Key words: microcontroller, nodemcu esp8266, optocoupler, load cell, mini servo sg90, smart infusion.

\section{PENDAHULUAN}

Pemberian cairan menggunakan infus adalah salah satu cara memasukkan cairan melalui intravena untuk memenuhi kebutuhan cairan, elektrolit, pemberian obat, serta pemberian makanan. Tujuan utama dari pemberian cairan infus untuk mengganti dan mempertahankan cairan yang dibutuhkan tubuh secara oral, selain itu permberian cairan infus juga dapat mengkoreksi dan mencegah gangguan cairan dan elektrolit, serta juga dapat memperbaiki keseimbangan asam basa.

Ditinjau dari kondisi sebenarnya bahwa pemantauan yang tepat terhadap pemberian cairan infus kepada pasien merupakan hal yang sangat penting untuk diperhatikan, maka diperlukan sebuah alat pemantau kondisi cairan infus untuk pasien.

Adapun cara yang saat ini digunakan oleh beberapa rumah sakit ialah menggunakan alat infusion pump. Alat ini dapat mendeteksi kelancaran dan volume infus serta memberi peringatan pada juru rawat di ruang pasien.

\section{METODE PENELITIAN}

\subsection{Alat dan Bahan}

Perangkat keras yang digunakan sebagai bahan-bahan untuk melakukan penelitian adalah sebagain berikut :

1. NodeMCU ESP8226 ESP 12E 
2. Modul Sensor Infrared

3. Mini Servo SG90

4. Modul Amplifier HX711

5. Modul Load Cell

6. LCD $16 \mathrm{x} 2$

7. Buzzer

8. Baterai Li-Ion 18650

9. Push button

10. Mika / Akrilik

11. Cairan Infus $500 \mathrm{ml}$

12. Infus Set (selang, keran infus, tabung infus, jarum infus)

13. Timah

14. Kabel Jumper

\subsection{Internet of Things}

Internet of Things adalah suatu konsep dimana objek tertentu punya kemampuan untuk mentransfer data lewat jaringan tanpa memerlukan adanya interaksi dari manusia ke manusia ataupun dari manusia ke perangkat komputer. Internet of Things leih sering disebut dengan singkatannya yaitu IoT. IoT ini sudah berkembang pesat mulai dari konvergensi teknologi nirkabel, microelectromechanical systems (MEMS), dan juga Internet. IoT ini juga kerap diidentifikasikan dengan RFID sebagai metode komunikasi. Walaupun begitu, IoT juga bisa mencakup teknologi-teknologi sensor lainnya, semacam teknologi nirkabel maupun kode QR yang sering kita temukan di sekitar kita. [13]

Adapun kemampuan dari IoT bermacam-macam contohnya dalam berbagi data, menjadi remote control, dan masih banyak lagi yang lainnya. Sebenarnya fungsinya termasuk juga diterapkan ke benda yang ada di dunia nyata, di sekitar kita.

\subsection{NodeMCU ESP8266}

NodeMCU adalah sebuah platform IoT yang bersifat open source. Terdiri dari perangkat keras (hardware) berupa System On Chip ESP8266 dari ESP8266 buatan Espressif System, juga firmware yang digunakan, yang menggunakan bahasa pemrograman scripting Lua. Istilah NodeMCU secara default sebenarnya mengacu pada firmware yang digunakan daripada perangkat keras development kit. [12]

$$
\text { Karena sifatnya yang open }
$$

source tentu akan banyak produsen yang memproduksinya dan mengembangkannya. Secara umum ada tiga produsen NodeMCU yang produknya kini beredar di pasaran: Amica, DOIT, dan Lolin/WeMos. Dengan beberapa varian board yang diproduksi yakni V1, V2 dan V3. Dibawah adalah gambar tampilan fisik dari NodeMCU ESP8266 V3 yang bisa dilihat ada gambar 1 . berikut.

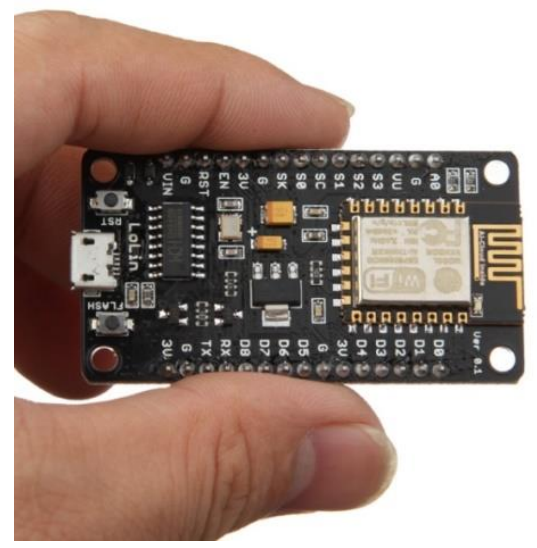

\section{Gambar 1. NodeMCU ESP8266 V3 Lo-Lin}

\subsection{Infus}

Pemasangan infus merupakan salah satu tindakan dasar dan pertama yang dilakukan oleh tenaga kesehatan, khususnya perawat sebagai awal dari rangkaian kegiatan pengobatan dan perawatan terhadap hampir semua jenis kasus baik itu gawat, darurat, kritis, ataupun sebagai tindakan profilaksis. Infus juga merupakan pemasukan suatu cairan atau obat ke dalam tubuh melalui rute intravena dengan laju konstan selama periode waktu tertentu. Infus dilakukan untuk seorang pasien yang membutuhkan obat sangat cepat atau membutuhkan pemberian obat secara pelan tetapi terus-menerus. 
Pemberian obat atau cairan ke dalam tubuh melalui mulut akan memasuki proses pencernaan terlebih dahulu sehingga tidak dengan cepat diserap oleh tubuh. Saat proses pencernaan juga dimungkinkan ada enzim pencernaan yang akan mengubah atau memecah obat yang diminum sehingga akan kurang efektif dan lebih baik jika langsung masuk ke dalam aliran darah melalui infus. Infus dilakukan dengan cara memasukkan sebuah jarum kecil ke alirah pembuluh darah.

Biasanya jarum di tanam di dekat siku-siku, pergelangan tangan, atau di bagian punggung tangan pasien. Selain pada bagian tangan, infus juga dapat dipasang pada bagian kaki. Kecepatan pasien menyerap cairan infus tergantung dari keadaan tubuh pasien dan penyakit yang diderita. Jumlah tetesan cairan infus setiap menitnya akan dipantau oleh seorang perawat. [7]

Tindakan ini merupakan tindakan life saving seperti pada kehilangan cairan yang banyak, dehidrasi dan syok, karena itu keberhasilan terapi dan cara pemberian yang aman diperlukan pengetahuan dasar tentang keseimbangan cairan dan elektrolit serta asam basa. [16] tujuan utama terapi intravena adalah mempertahankan atau mengganti cairan tubuh yang mengandung air, elektrolit, vitamin, protein, lemak dan kalori yang tidak dapat dipertahankan melalui oral, mengoreksi dan mencegah gangguan cairan dan elektrolit, memperbaiki keseimbangan asam basa, memberikan tranfusi darah, menyediakan medium untuk pemberian obat intravena, dan membantu pemberian nutrisi parenteral.

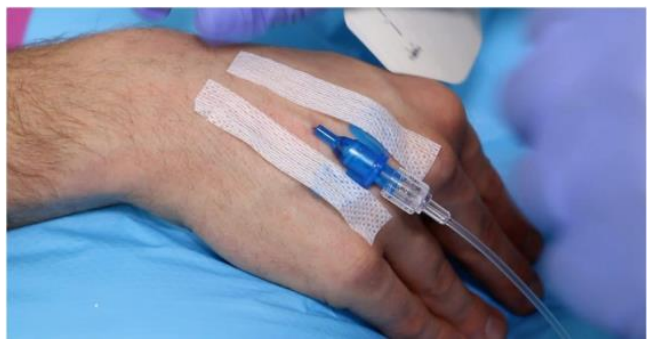

Gambar 2. Proses Infus

\subsection{Sensor Optocoupler}

Optocoupler adalah komponen elektronika yang berfungsi sebagai penghubung berdasarkan cahaya optik. Pada dasarnya optocoupler terdiri dari 2 bagian utama yaitu transmitter yang berfungsi sebagai pengirim cahaya optik dan receiver yang berfungsi sebagai pendeteksi sumber cahaya. Masing-masing bagian Optocoupler (transmitter dan receiver) tidak memiliki hubungan konduktif rangkaian secara langsung tetapi dibuat sedemikian rupa dalam satu kemasan komponen.

Pada prinsipnya, Optocoupler dengan kombinasi LED-phototransistor adalah Optocoupler yang terdiri dari sebuah komponen LED (Light Emitting Diode) yang memancarkan cahaya infra merah (Infrared LED) dan sebuah komponen semikonduktor yang peka terhadap cahaya (phototransistor) sebagai bagian yang digunakan untuk mendeteksi cahaya infra merah yang dipancarkan oleh IR LED.

Sistem akan bekerja jika sinar inframerah yang dipancarkan ke suatu benda didepannya dan diterima oleh receiver dengan jarak yang sudah dikondisikan. Pemancar pada sistem ini terdiri atas sebuah LED inframerah yang dilengkapi dengan rangkaian yang mampu membangkitkan data untuk dikirimkan melalui sinar inframerah, sedangkan pada bagian penerima biasanya terdapat foto transistor, foto dioda, atau modul infrared yang berfungsi untuk menerima sinyal inframerah yang dikirimkan oleh pemancar. Sensor yang beredar dipasaran ditampilkan pada gambar 2.3 adalah sensor optocoupler encoder yang menggunakan infrared sebagai transmitter dan photodioda sebagai receiver.[4] 


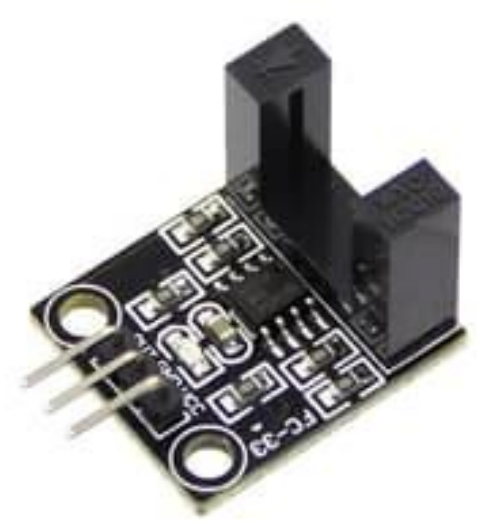

Gambar 3. Modul Sensor Optocoupler Encoder

\subsection{Liquid Crystal Digital (LCD)}

Display elektronik adalah salah satu komponen elektronika yang berfungsi sebagai tampilan suatu data, baik karakter, huruf ataupun grafik. LCD (Liquid Cristal Display) adalah salah satu jenis display elektronik yang dibuat dengan teknologi CMOS logic yang bekerja dengan tidak menghasilkan cahaya tetapi memantulkan cahaya yang ada di sekelilingnya terhadap front-lit atau mentransmisikan cahaya dari back-lit. LCD (Liquid Cristal Display) berfungsi sebagai penampil data baik dalam bentuk karakter, huruf, angka ataupun grafik.

LCD adalah lapisan dari campuran organik antara lapisan kaca bening dengan elektroda transparan indium oksida dalam bentuk tampilan seven-segment dan lapisan elektroda pada kaca belakang. Ketika elektroda diaktifkan dengan medan listrik (tegangan), molekul organik yang panjang dan silindris menyesuaikan diri dengan elektroda dari segmen. Microntroller pada suatu LCD (Liquid Cristal Display) dilengkapi dengan memori dan register. [14] Berikut tampilan fisik dari LCD yang bisa dilihat pada gambar 4 dibawah.

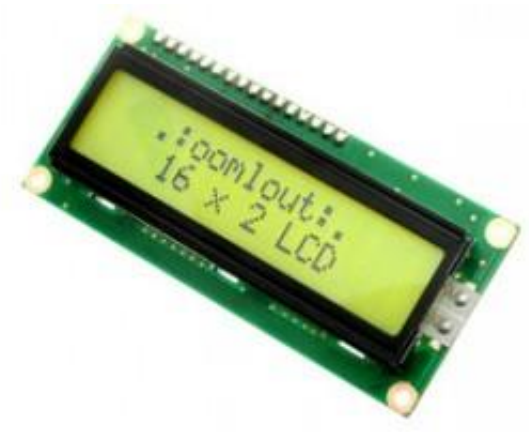

Gambar 4. Liquid Crystal Display (LCD)

\subsection{Mini Servo SG90}

Motor servo adalah sebuah motor DC dengan sistem umpan balik tertutup dimana posisi rotornya akan diinformasikan kembali ke rangkaian konntrol yang ada di dalam motor servo. Motor servo terdiri dari sebuah motor DC, serangkaian roda gigi, potensiometer dan rangkaian kontrol. Sudut dari sumbu motor servo diatur berdasarkan lebar pulsa yang dikirim melalui kaki sinyal dari kabel motor servo.

Prinsip kerja motor servo ialah dengan memberikan sinyal modulasi lebar pulsa (Pulse Wide Modulation / PWM) melalui kabel kontrol. Lebar pulsa sinyal kontrol yang diberikan akan menentukan posisi sudut putaran dari poros motor servo. Sebagai contoh lebar pulsa dengan waktu $1,5 \mathrm{~ms}$ (mili second) akan memutar poros motor servo ke posisi sudut $90^{\circ}$. Bila pulsa lebih pendek dari $1,5 \mathrm{~ms}$ maka akan berputar kearah posisi $0^{\circ}$ atau ke kiri (berlawanan dengan arah jarum jam), sedangkan bila pulsa yang diberikan lebih lama dari $1,5 \mathrm{~ms}$ maka poros motor servo akan berputar ke arah $180^{\circ}$ atau ke kanan (searah jarum jam). Berikut adalah bentuk fisik dari mini servo SG90 yang bisa dilihat pada gambar 5 berikut. [3] 


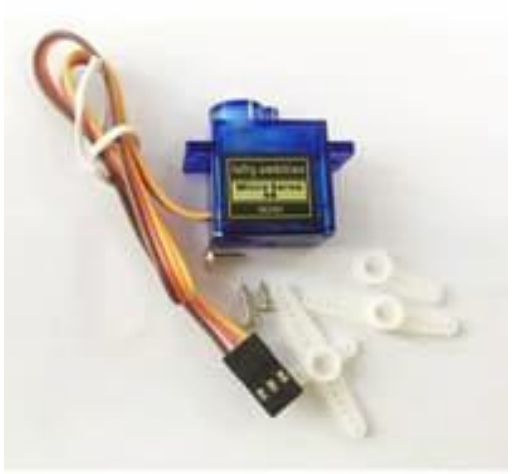

Gambar 5. Mini Servo SG90

\subsection{Sensor Load Cell}

Sensor Load Cell merupakan sensor yang dirancang untuk mendeteksi tekanan atau berat sebuah beban. Sensor load cell umumnya digunakan sebagai komponen utama pada sistem timbangan digital. Contoh lainnya diaplikasikan pada jembatan timbangan yang berfungsi untuk menimbang berat dari truk pengangkut bahan baku. Pengukuran yang dilakukan oleh load cell menggunakan prinsip tekanan. Dibawah ini adalah gambar bentuk fisik dari load cell yang bisa kita lihat pada gambar 6. [5]

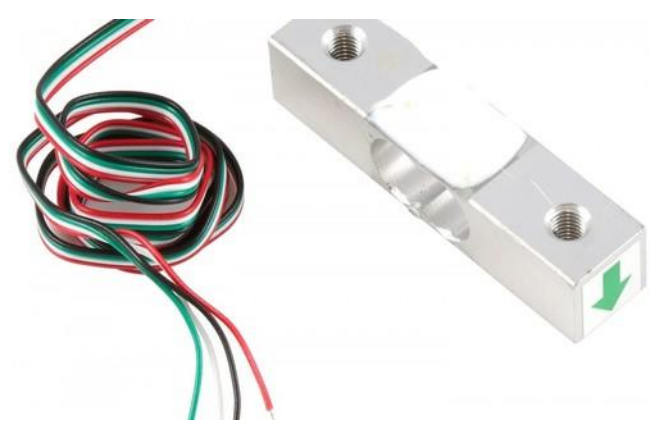

Gambar 6. Sensor Load Cell

\subsection{Arduino IDE}

Arduino IDE (Integrated Development Enviroment) merupakan perangkat lunak (software) yang telah disiapkan oleh arduino untuk para perancang agar dapat melakukan berbagai macam proses yang berkaitan dengan pemrograman perangkat keras (hardware) arduino. [15] Pada software inilah arduino dilakukan pemrograman untuk melakukan fungsi-fungsi yang dibenamkan melalui sintaks pemrograman. Arduino menggunakan bahasa pemrograman $\mathrm{C}$ yang dimodifikasi. Jadi bisa kita sebut bahasa $\mathrm{C}$ disini dengan bahasa pemrograman $\mathrm{C}$ versi Arduino.

Didalam arduino sendiri sudah terdapat IC mikrokontroler yang sudah ditanam program yang bernama Bootloader. Fungsi dari bootloader tersebut adalah untuk menjadi penengah antara compiler arduino dan mikrokontroler. Berikut adalah tampilan software Arduino IDE bisa kita liat pada gambar 7 berikut.

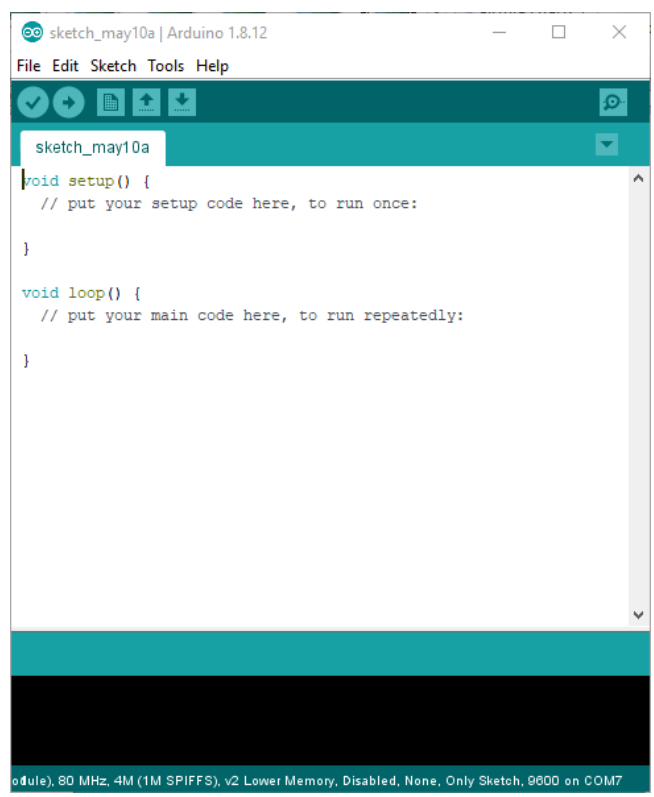

Gambar 7. Software Arduino IDE

\subsection{Delphi XE8}

Delphi adalah bahasa pemrograman tingkat tinggi yang diketik dengan kuat berdasarkan Object Pascal yang mendukung pemrograman berorientasi objek. Itu juga dapat menggabungkan kode yang ditulis dalam bahasa assembly dan bahasa tingkat rendah lainnya, memberikan delphi akses tidak langsung ke perangkat keras mesin. Kekuatan utamanya adalah bahwa ia mengkompilasi dengan sangat cepat, artinya aplikasi delphi dengan basis kode 
yang relatif besar dapat dikompilasi dan dijalankan pada mesin dengan sumber daya terbatas. [6]

Pemrograman Delphi adalah pemrograman yang cocok digunakan untuk project dengan waktu pengerjaan yang sebentar juga tampilan interface yang sederhana dan untuk jangkauan sistemnya mulai dari yang sederhana sampai yang kompleks. [9] Dibawah ini adalah tampilan dari IDE delphi XE8 yang bisa dilihat pada gambar 2.9 berikut.

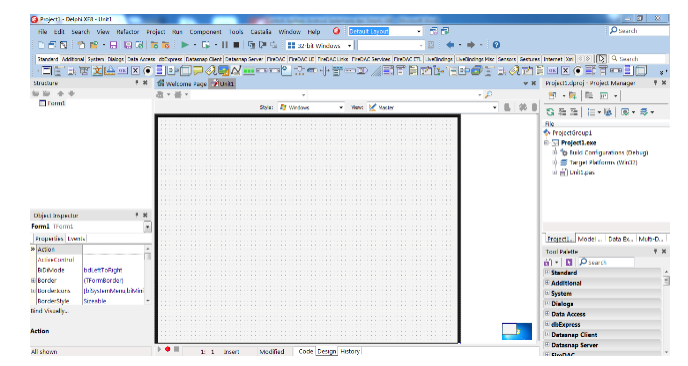

\section{Gambar 8. Tampilan IDE Delphi XE8}

\section{HASIL DAN PEMBAHASAN}

\subsection{Hasil Penelitian}

Berikut adalah hasil perancangan dan pengujian yang diperoleh.

\subsubsection{Bentuk Fisik Alat}

Alat untuk sistem infus cerdas dirancang menjadi dua bagian, yaitu sensor infus dan panel kontrol sistem infus cerdas. Pada bagian sensor infus terdapat sensor load cell, sensor optocoupler, dan mini servo, sedangkan pada panel kontrol infus cerdas terdapat komponen baterai, saklar, modul stepdown 3A, nodemcu esp8266, LCD 16x2 (Liquid Crystal Display), buzzer, saklar toogle, dan tiga buah push button (up, down, reset). [10]

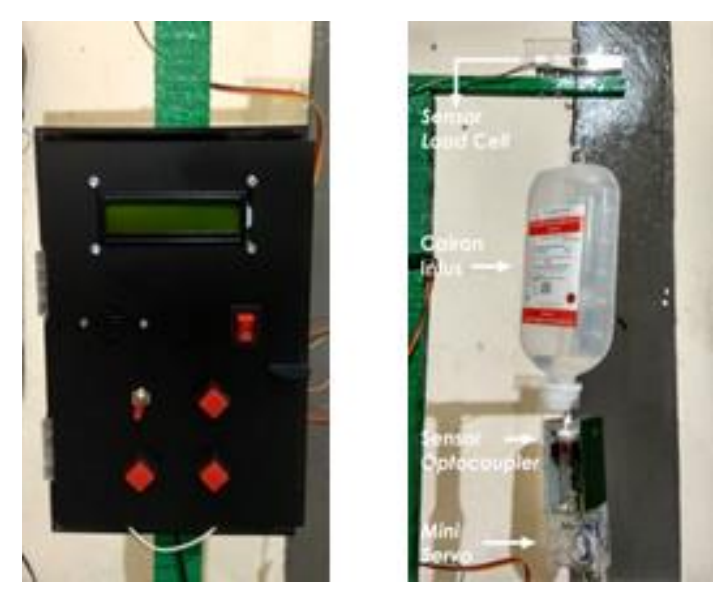

Gambar 9. Panel Kontrol dan Sensor Infus

Nodemcu esp8266 berfungsi sebagai pusat pengontrolan alat sistem infus cerdas. Modul mikrokontroler nodemcu esp8266 ini memiliki sembilan pin digital dan satu pin analog.

Modul sensor load cell, dan sensor optocoupler berfungsi sebagai inputan, sedangkan untuk outputnya adalah LCD 16x2, mini servo sg90, dan buzzer. Nilai-nilai data yang diterima dari sensor akan diolah oleh mikrokontroler nodemcu esp8266, kemudian akan dikirimkan ke komputer server ataupun smartphone sebagai client. Pada perangkat yang berfungsi sebagai input, modul load cell beserta modul amplifier HX711 terhubung pada nodemcu esp8266 dengan pin DT pada pin D7 nodemcu dan pin SLK pada pin D8 nodemcu. Output sensor optocoupler terhubung pada pin D5 nodemcu esp8266. Push button yang digunakan untuk mengontrol mini servo ke kiri dan ke kanan terhubung masing-masing D3 ke kiri dan D1 ke kanan.

Untuk output dari sistem infus cerdas terdapat LCD 16x2, mini servo dan juga buzzer. Pin PWM dari mini servo sg90 terhubung pada pin D6 nodemcu esp8266. Untuk LCD sudah menggunakan modul I2C agar dapat menyederhanakan penggunaan pin pada mikrokontroller, dengan hanya dua pin keluaran yaitu pin SDA dan SCL. Pin SDA terhubung pada pin D2 nodemcu esp8266 dan pin SCL terhubung pada pin D1 nodemcu 
esp8266. Dan untuk buzzer terhubung dengan pin A0 nodemcu esp8266. Skema rangkaian alat ditampilkan pada gambar 11 berikut.

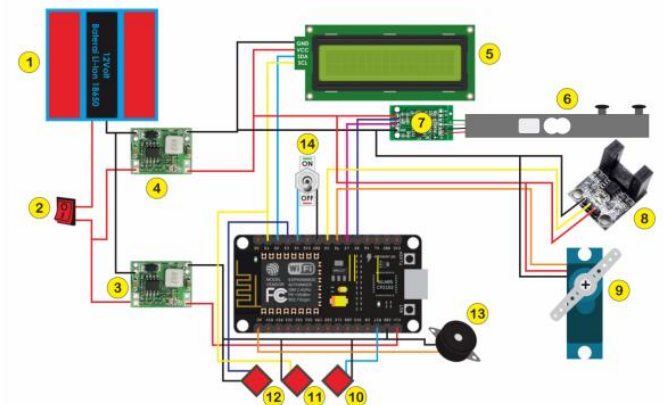

$$
\begin{array}{lll}
\text { Keterangan : } & & \\
\text { 1. Baterai 18650 3S } & \text { 6. Sensor Load Cell } 1 \mathrm{Kg} & \text { 11. Push Button Kanan } \\
\text { 2. Saklar 2 Pin } & \text { 7. Modul Amplifier HX711 } & \text { 12. Push Button Kiri } \\
\text { 3. Stepdown 3A MP1584 } & \text { 8. Sensor Optocoupler LM393 } & \text { 13. Buzzer } \\
\text { 4. Stepdown 3A MP1584 } & \text { 9. Mini Servo SG90 } & \text { 14. Toogle Switch } \\
\text { 5. LCD 16 } 16 & \text { 10. Push Button Reset } &
\end{array}
$$

\section{Gambar 10. Skema Rangkaian Alat}

\subsubsection{Rangkaian Power Supply}

Power supply yang digunakan untuk memberikan suplai daya pada alat sistem infus cerdas ini yaitu berupa baterai Li-Ion 186504 VDC dirangkai seri tiga buah sehingga dapat menghasilkan tegangan 12 VDC yang kemudian dimasukkan ke dua buah modul DCDC stepdown MP1584 menjadi 5 VDC. Modul stepdown pertama digunakan untuk menyuplai mikrokontroler nodemcu esp8266, dan untuk modul stepdown kedua digunakan untuk mensuplai sensor load cell, sensor optocoupler, mini servo sg90, dan LCD 16x2. Gambar 12 menampilkan rangkaian power supply yang digunakan pada sistem infus cerdas.

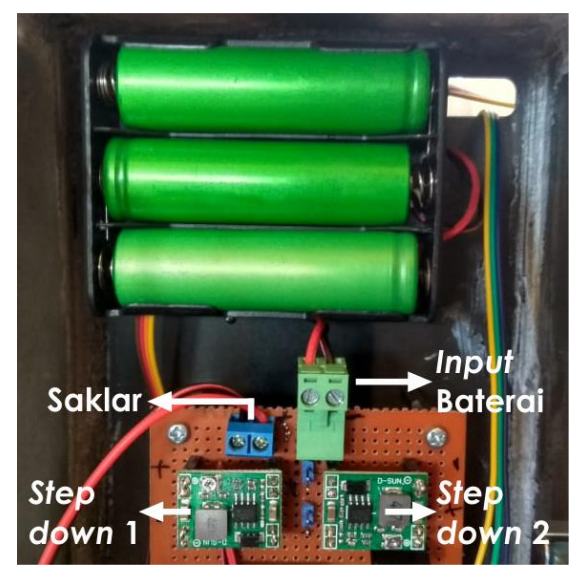

Gambar 11. Rangkaian Power Supply

\subsubsection{Modul Sensor Optocoupler LM393}

Modul sensor optocoupler LM393 digunakan untuk mendeteksi halangan yang berada diantara infrared dan photodioda. Pada penelitian ini, modul sensor optocoupler akan aktif jika kondisi nilai digitalnya "0" (active low) dan digunakan untuk mendeteksi jumlah tetesan air infus tiap menitnya. Tiap tetes infus yang melewati sensor akan dikalkulasikan dalam hitungan menit. Gambar 13 dibawah adalah gambar sensor optocoupler yang terpasang pada alat.

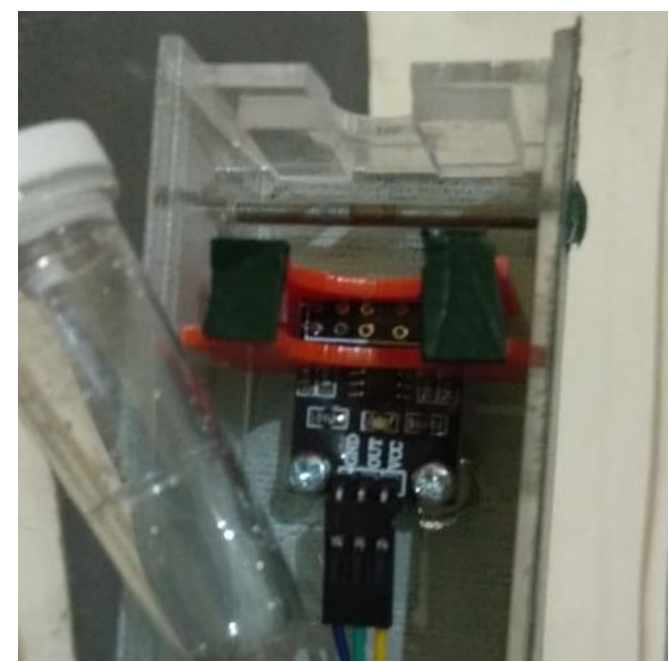

Gambar 12. Modul Sensor Optocoupler

LM393

\subsubsection{Sensor Load Cell dan Amplifier HX711}

Sensor load cell yang digunakan pada penelitian rancang bangun sistem infus cerdas adalah sensor dengan kemampuan ukur satu kilogram. Alasan mengapa sensor ini dipilih adalah karena beban yang akan diukur oleh sensor tidak lebih dari satu kilogram, tepatnya 654 gram (cairan infus, sensor infus, mini servo, frame akrilik, dan infus set). Dibawah ini adalah gambar sensor load cell yang terpasang pada sistem infus cerdas. 


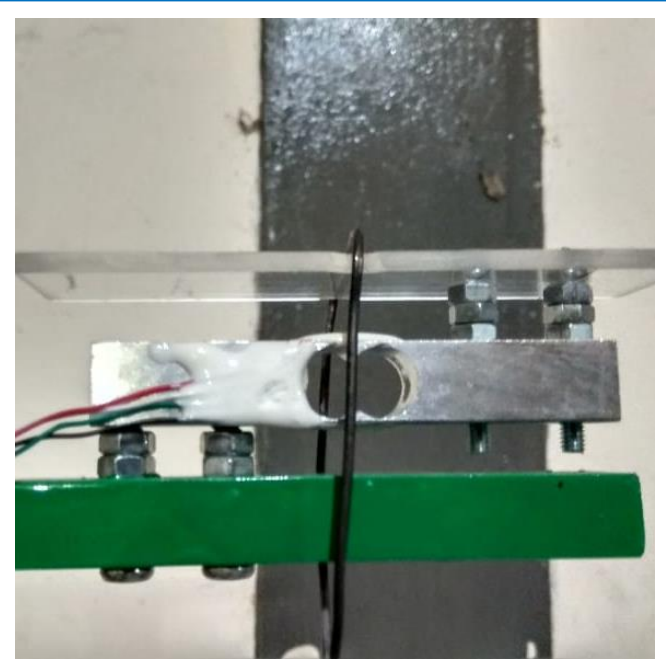

Gambar 13. Sensor Load Cell $1 \mathrm{Kg}$

Modul amplifier HX711 adalah modul yang digunakan untuk menguatkan output dari sensor load cell sehingga bisa dibaca oleh mikrokontroller. Modul ini memerlukan suplai 5 VDC untuk dapat bekerja, dua pin output yang terhubung ke mikrokontroler yaitu pin DT dan CLK, serta ada enam pin input. Berikut adalah gambar 4.9 modul amplifier HX711 yang digunakan pada sistem infus cerdas dan pada gambar 15 skema rangkaian modul amplifier hx711.

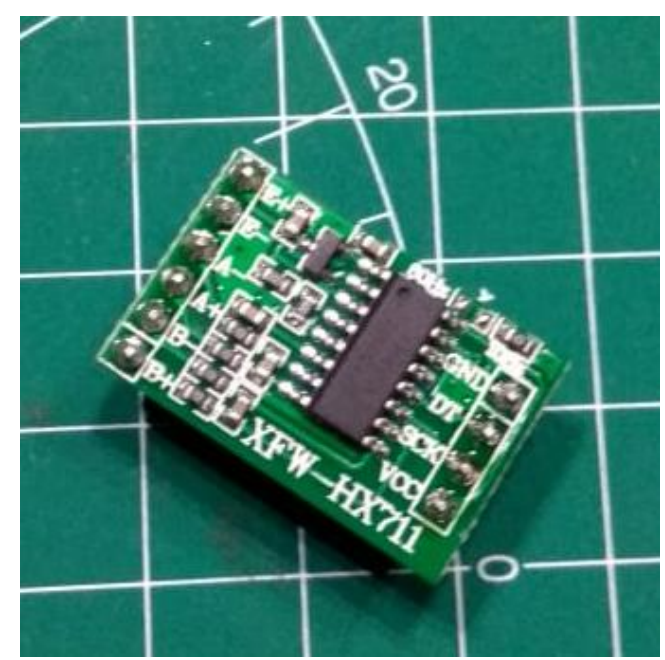

Gambar 14. Modul Amplifier HX711

\subsubsection{Mini Servo SG90 dan Push Button}

Mini servo SG90 berfungsi sebagai penggerak untuk mengatur keran selang infus.
Mikro servo akan bergerak dari nol sampai sembilan puluh derajar untuk mengatur kecepatan tetesan infus. Servo SG mempunyai tegangan kerja yaitu : 3,5 - 8,8 VDC. Pada mini servo ini terdapat tiga kabel yang berbeda warna dan terhubung ke nodemcu dengan menggunakan pin D6 yang berfungsi sebagai output. Mini servo akan bergerak ke kiri dan ke kanan untuk mengatur tekanan pada selang infus. Memutar mini servo ke kiri akan semakin menjepit selang infus, dengan demikian laju tetesan cairan infus akan berkurang. Dan apabila mini servo diputar ke kanan maka selang terbuka, dengan demikian laju tetesan cairan infus akan bertambah. Bentuk fisik mini servo sg90 pada alat dapat dilihat pada gambar 16.

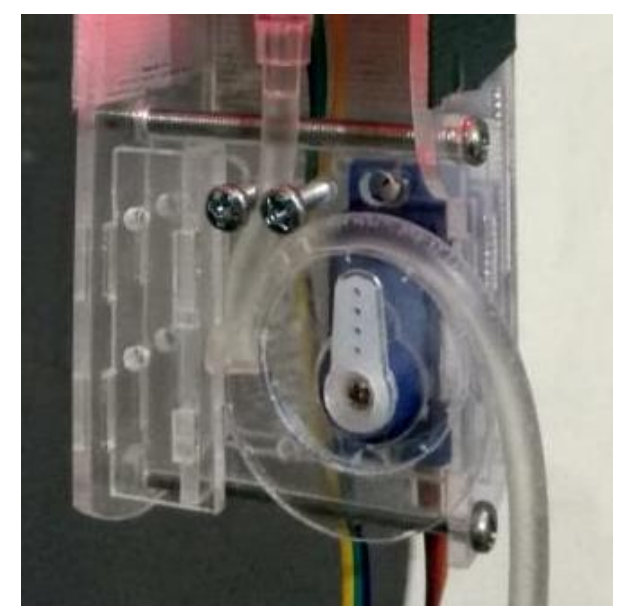

Gambar 15. Mini Servo SG90

\subsubsection{Software/Aplikasi Sistem Infus Cerdas pada PC dan Smartphone}

Software/aplikasi yang dibuat menggunakan Delphi XE8 bertujuan sebagai interface antara arduino dengan PC dan smartphone. Fungsi utama dari aplikasi ini adalah menampilkan kondisi dari sensor load cell dan sensor optocoupler yang terpasang pada tiang infus. 


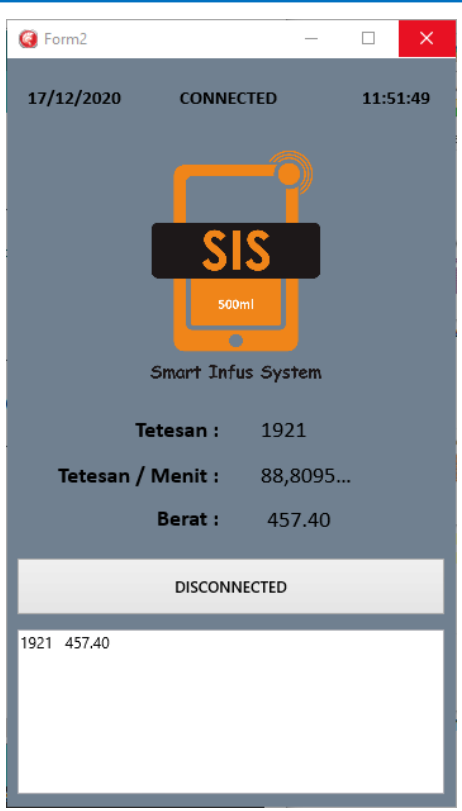

Gambar 16. Tampilan Aplikasi Sistem Infus Cerdas pada PC dan Smartphone

\subsection{Pengujian Alat}

Pengujian alat dilakukan dengan tujuan untuk mengetahui apakah alat yang dibuat telah berfungsi dengan baik dan sesuai dengan sistem yang telah direncanakan atau belum. Pada penelitian ini dilakukan percobaan sebanyak tiga kali dalam waktu satu hari. Dengan lama waktu percobaan pertama dan kedua selama empat puluh lima menit dan untuk waktu percobaan ketiga selama dua puluh tujuh menit.

\subsubsection{Pengujian Pertama}

Pada pengujian pertama yang dilakukan dengan durasi percobaan empat puluh lima menit. Percobaan dilakukan pada tanggal 17 desember 2020 sistem dinyalakan mulai pukul 10:38 dan dimatikan pada pukul 11:23 WITA. Dengan keadaan mini servo diatur pada posisi $85^{\circ}$.
Tabel 1 Pengujian Alat Sistem Infus Cerdas Pengujian Pertama

\begin{tabular}{|c|c|c|c|c|}
\hline No. & $\begin{array}{c}\text { Waktu } \\
\text { (menit) }\end{array}$ & Tetesan/menit & $\begin{array}{c}\text { Total } \\
\text { Tetesan }\end{array}$ & $\begin{array}{c}\text { Berat } \\
\text { (gr) }\end{array}$ \\
\hline 1. & 1 & 40 & 41 & 623,00 \\
\hline 2. & 5 & 46,4 & 234 & 625,85 \\
\hline 3. & 10 & 48 & 475 & 619,22 \\
\hline 4. & 15 & 48,07 & 719 & 612,16 \\
\hline 5. & 20 & 47,73 & 940 & 605,88 \\
\hline 6. & 25 & 47,37 & 1171 & 599,43 \\
\hline 7. & 30 & 46,96 & 1406 & 592,77 \\
\hline 8. & 35 & 46,48 & 1643 & 586,24 \\
\hline 9. & 40 & 45,97 & 1841 & 582,10 \\
\hline 10. & 45 & 45,53 & 2073 & 575,66 \\
\hline
\end{tabular}

Untuk melihat kondisi jumlah cairan infus tetesan permenit dan berat level cairan infus dapat dilihat pada gambar 18 grafik pengujian pertama.

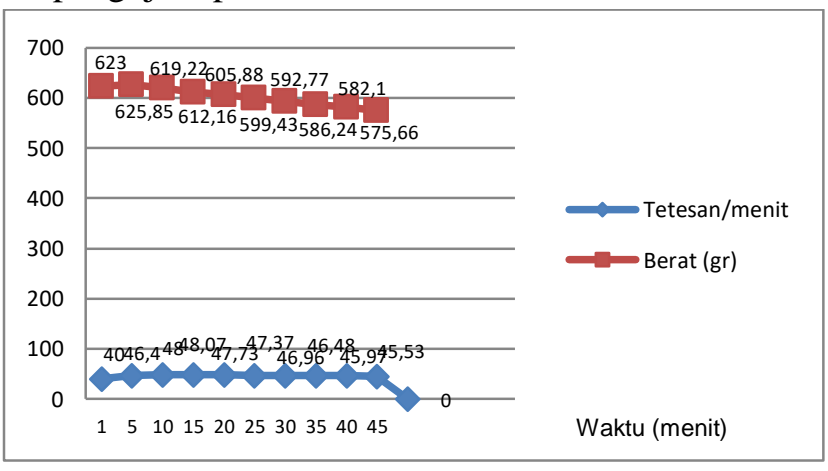

\section{Gambar 17. Grafik Pengujian Pertama}

Pada kondisi ini tetesan infus berjalan sangat lambat, sehingga untuk satu tetesan terbaca dua tetes oleh sensor optocoupler. Dengan perbedaan perhitungan ini, dapat dikatakan bahwa presentase eror dari pembacaan sensor sebesar $100 \%$. Hal ini disebabkan oleh tetesan infus yang terbaca dua kali oleh sensor karena satu tetesan cairan infus yang terbaca lagi setelah lebih dari 50 mili second.

\subsubsection{Pengujian Kedua}


Pada pengujian pertama yang dilakukan dengan durasi percobaan empat puluh lima menit. Percobaan dilakukan pada tanggal 17 desember 2020 sistem dinyalakan mulai pukul 11:30 dan dimatikan pada pukul 12:16 WITA. Dengan keadaan mini servo diatur pada posisi $100^{\circ}$.

Tabel 2. Pengujian Alat Sistem Infus Cerdas

Pengujian Kedua

\begin{tabular}{|c|c|c|c|c|}
\hline No. & $\begin{array}{c}\text { Waktu } \\
(\text { menit) }\end{array}$ & $\begin{array}{c}\text { Tetesan/ } \\
\text { menit }\end{array}$ & $\begin{array}{c}\text { Total } \\
\text { Tetesa } \\
\text { n }\end{array}$ & $\begin{array}{c}\text { Berat } \\
(\mathbf{g r})\end{array}$ \\
\hline 1. & 1 & 83 & 132 & 564,51 \\
\hline 2. & 5 & 87 & 580 & 537,61 \\
\hline 3. & 10 & 87,63 & 1021 & 511,06 \\
\hline 4. & 15 & 88,12 & 1456 & 485,11 \\
\hline 5. & 20 & 88,80 & 1921 & 457,40 \\
\hline 6. & 25 & 89,34 & 2370 & 430,64 \\
\hline 7. & 30 & 89,80 & 2835 & 403,01 \\
\hline 8. & 35 & 90,13 & 3308 & 374,92 \\
\hline 9. & 40 & 90,43 & 3758 & 348,08 \\
\hline 10. & 45 & 90,63 & 4215 & 321,30 \\
\hline
\end{tabular}

Untuk melihat kondisi jumlah cairan infus tetesan permenit dan berat level cairan infus dapat dilihat pada gambar 19 grafik pengujian kedua.

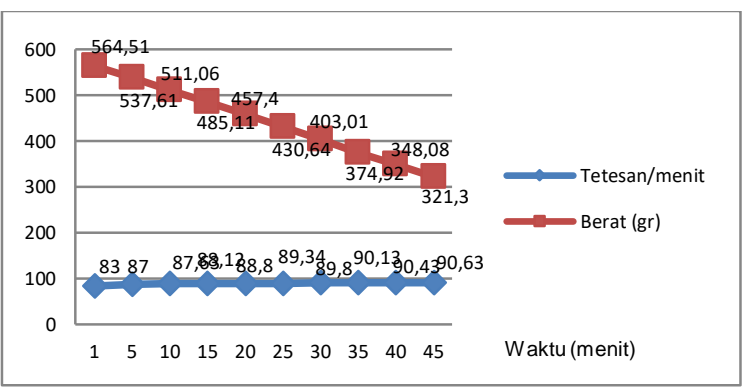

Gambar 18. Grafik Pengujian Kedua

Pada pengujian kedua, pembacaan sensor normal dan tidak ada tetesan yang hilang atau tidak terbaca. hanya saja pada kondisi ini jumlah tetesan cairan infus terbilang sangat tinggi.

\subsubsection{Pengujian Ketiga}

Pada pengujian ketiga akan dilakukan dengan durasi percobaan dua puluh tujuh menit, namun setiap tiga menit akan bertambah jarak antara alat infus cerdas dengan client PC ataupun smartphone. Percobaan akan dilakukan pada tanggal 17 desember 2020 sistem dinyalakan mulai pukul 21:41 dan akan dimatikan pad pikul 20:07 WITA. Dengan keadaan mini servo diatur pada posisi $95^{\circ}$.

Tabel 3. Pengujian Alat Sistem Infus

\section{Cerdas}

Pengujian Ketiga

\begin{tabular}{|c|c|c|c|c|c|}
\hline No. & $\begin{array}{c}\text { Jarak } \\
(\mathbf{m})\end{array}$ & $\begin{array}{c}\text { Waktu } \\
(\mathbf{m e n i t})\end{array}$ & $\begin{array}{c}\text { Tetesan } \\
\text { /menit }\end{array}$ & $\begin{array}{c}\text { Total } \\
\text { Tetesan }\end{array}$ & $\begin{array}{c}\text { Berat } \\
(\mathbf{g r})\end{array}$ \\
\hline 1. & 1 & 1 & 10 & 10 & 320 \\
\hline 2. & 4 & 3 & 52 & 128 & 313,43 \\
\hline 3. & 7 & 6 & 53,6 & 269 & 305,51 \\
\hline 4. & 10 & 9 & 54,62 & 441 & 295,69 \\
\hline 5. & 13 & 12 & 55,36 & 612 & 285,98 \\
\hline 6. & 16 & 15 & 54,64 & 772 & 275,92 \\
\hline 7. & 19 & 18 & 55,35 & 945 & 266,10 \\
\hline 8. & 22 & 21 & 55,63 & 1104 & 257,17 \\
\hline 9. & 25 & 24 & - & - & - \\
\hline 10. & 28 & 27 & - & - & - \\
\hline
\end{tabular}

Untuk melihat kondisi jumlah cairan infus tetesan permenit dan berat level cairan infus dapat dilihat pada gambar 20 grafik pengujian ketiga.

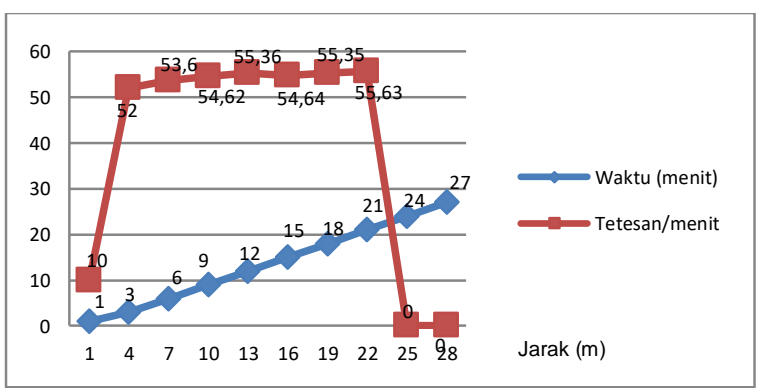

Gambar 19. Grafik Pengujian Ketiga

Pada pengujian ketiga, pembacaan sensor berjalan dengan normal dan tidak ada jumlah tetes cairan infus yang hilang. Namun percobaan berakhir pada jarak 25 meter, 
dikarenakan koneksi antara client PC dan nodemcu esp8266 yang terputus.

\section{KESIMPULAN}

Setelah melakukan semua proses penelitian yang telah direncanakan pada penelitian rancang bangun sistem infus cerdas, maka diperoleh beberapa kesimpulan sebagai berikut :

1. Penelitian ini berhasil membuat alat dan suatu sistem infus cerdas sesuai dengan yang direncanakan, alat ini dapat menampilkan informasi jumlah total tetesan cairan infus, jumlah tetesan cairan infus permenit, dan kondisi level cairan infus yang tersisa.

2. LCD yang terpasang pada panel kontrol dapat menampilkan informasi kamar, jumlah total tetesan cairan infus, dan level cairan infus. Pada aplikasi PC dan smartphone dapat menampilkan jumlah total tetesan cairan infus, jumlah tetesan cairan infus permenit, dan level cairan infus.

3. Untuk mengatur posisi putaran mini servo keran infus, dapat diatur saat alat tidak atau belum terkoneksi dengan client PC ataupun smartphone.

4. Sensor optocoupler yang digunakan sangat peka terhadap cahaya, sehingga dapat mengganggu pembacaaan tetesan cairan infus. Solusi untuk mengataasi masalah ini yaitu dengan menutupi frame yang terbuat dari akrilik transparan dengan isolasi hitam tebal.

5. Sensor optocoupler yang digunakan dapat mendeteksi setiap tetesan cairan infus. Semakin laju tetesan cairan infus, pembacaan juga semakin akurat.

6. Sebaliknya, bila tetesan terlalu lambat sampai sepuluh tetesan permenit jika dihitung manual maka pembacaan sensor bisa eror satu tetesan terbaca dua tetes. Hal ini disebabkan oleh tetesan infus yang terbaca dua kali oleh sensor karena satu tetesan cairan infus yang terbaca lagi setelah lebih dari 50 mili second.

7. Pada percobaan yang dilakukan dengan mengartur mini servo pada posisi $85^{\circ}$, permbacaan sensor mengalami eror dengan selisih $100 \%$. Hal ini dikarenakan tetesan cairan infus yang terlalu lambat sehingga membuat sensor membaca dua kali untuk setiap tetesan.

8. Sedangkan pada percobaan yang dilakukan dengan mengatur mini servo pada posisi $100^{\circ}$, pembacaan sensor sangat baik dan tidak memiliki eror sama sekali. Hanya saja pada percobaan ini jumlah tetesan infus permenitnya terhitung sangat tinggi, yaitu berada pada range 87-90 tetes permenit.

9. Pada percobaan yang dilakukan, jarak maksimal pengiriman data dan koneksi antara nodemcu dan PC sejauh 22 meter. Pada jarak 24 meter nodemcu dan PC sudah tidak terkoneksi.

\section{DAFTAR PUSTAKA}

[1] Ajie, 2015. Contoh Aplikasi Android Sederhana Dengan Delphi XE8.http://saptaji.com/2015/08/01/contoh -aplikasi-android-sederhana-dengandelphi-xe8. Diakses pada 23:30 WITA, pada 14 April 2020.

[2] Alauddin Muwahhid, Hanifah Rahmi Fajrin, Susilo Ari Wibowo, 2020. Alat Pengatur Aliran Infus Dilengkapi Sensor Occlusion dan Sensor Empty Berbasis Arduino. Naskah Publikasi Program Studi D3 Teknologi Elektro-Medis. Program Vokasi, Universitas Muhammadiyah Yogyakarta. 
[3] Arfi, 2019. Cara menggunakan SG-90 Mini Motor Servo, https://mechasolution.co.id/caramenggunakan-sg-90-mini-motor-servo. Diakses pada 21:45 WITA, 10 April 2020.

[4] Dickson Kho, 2019. Pengertian Optocoupler dan Prinsip Kerjanya, https://teknikelektronika.com/pengerti an-optocoupler-fungsi-prinsip-kerjaoptocoupler. Diakses pada 4:42 WITA, 15 April 2020.

[5] HME FT UNTIRTA, 2018. Memahami Sensor Berat "Load Cell". https://www.hmeftuntirta.com/2018/0 6/memahami-sensor-berat-load-cell. Diakses pada 17:44, 13 April 2020.

[6] Juliawan Gisdaronli H. A. dan Muh. Febriansyah, 2018. Rancang Bangun Sistem Informasi Parkir Mobil Online Berbasis Delphi dan Arduino. Skripsi Program Studi S1 Teknik Elektro. Jurusan Teknik Elektro, Fakultas Teknik, Universitas Tadulako, Kota Palu, Sulawesi Tengah.

[7] Nerslicious , 2018. SOP Pemasangan Infus Lengkap Sesuai Standar Akreditasi, https://www.nerslicious.com/soppemasangan-infus. Diakses pada 18:47 WITA, 10 April 2020.

[8] Nugraha Fauzi, 2018. Cara Menghitung Tetesan Infus Lengkap https://www.nerslicious.com/caramenghitung-tetesan-infus-lengkap.

Diakses pada 11.00 WITA, 13 Desember 2020.

[9] Repsi Risyan, 2019. Apa Itu Pemrograman Delphi ?. https://www.monitorteknologi.com/apaitu-pemrograman-delphi. Diakses pada 00:24 WITA, 14 April 2020.
[10] Ryan Adolf Tohuro dan I Ketut Suliawan, 2017. Rancang Bangun Sistem Infus Otomatis Berbasis Mikrokontroler Atmega 8535. Skripsi Program Studi S1 Teknik Elektro. Jurusan Teknik Elektro, Fakultas Teknik, Universitas Tadulako, Sulawesi Tengah.

[11] Septyana Riskitasari, Fahmiwati Hamida, Wahyu Aulia Nurwicaksana, Nizar Arizaldi dan Supriatna Adhisugiwigno, 2017. Sistem Monitoring Level Dan Tetesan Cairan Intravena Pada Pasien Rawat Inap Menggunakan Komunikasi NRF24L01. Prosiding SNATIF Ke-4 Tahun 2017. Fakultas Teknik, Universitas Muria Kudus.

[12] Tedy Tri Saputro, 2017. Mengenal NodeMCU : Pertemuan Pertama, https://embeddednesia.com/v1/tutorialnodemcu-pertemuan-pertama. Diakses pada 1:30 WITA, 11 April 2020.

[13] Tim Dewa Web, 2018. Internet of things : Panduan lengkap, https://www.dewaweb.com/blog/internetof-things. Diakses pada 11:22 WITA, 10 April 2020.

[14] Tim Elektronika Dasar, 2018. LCD (Liquid Cristal Display). https://elektronika-dasar.web.id/lcdliquid-cristal-display. Diakses pada 14:35, 13 April 2020.

[15] Ziger Wix, 2019. Arduino IDE, Pengertian dan Istilah Yang Sering Digunakan,

https://www.idebebas.com/arduino-ide.

Diakses pada 23:00 WITA, 10 April 2020.

[16] Hidayat, A, A. (2008) Metode Penelitian Kebidanaan dan Taknik Analisa Data. Jakarta; Salemb Medika. 